\title{
Mere ro i Tjetjenien, men flere overgreb
}

Oleg Orlov

\section{Selv om der meldes om aftagende vold i Tjetje- nien, led magtorganerne de største tab sidste år i netop Tjetjenien}

I Nordkaukasus (herunder også i Tjetjenien) står den russiske stat over for en bevæbnet undergrundsbevægelse, der benytter terrormetoder i sin kamp. De statslige magtorganer benytter sig af statsterror i kampen imod undergrundsbevægelsen, herunder den terroristiske.

I foråret 2009 blev det klart, at en alvorlig destabilisering var begyndt $\mathrm{i}$ Tjetjenien. Denne destabilisering blev fremkaldt af alt, hvad republikkens myndigheder og magtorganer havde foretaget sig tidligere. (Samtidig erklærede Moskva antiterroraktionerne for afsluttet. Red.)

I 2007 og i 1. halvdel af 2008 kunne det se ud til, at der i Den Tjetjenske Republik var opnået fred og stabilitet - om end på bekostning af alvorlige krænkelser af menneskerettighederne. Intensiviteten af væbnede sammenstød faldt, magtorganerne led færre tab, og menne- skerettighedsforkæmperne meldte om færre tilfælde af vilkårlig vold fra statens repræsentanters side.

Men begivenhedernes udvikling fra slutningen af 2008 vidner om det modsatte.

I sommeren 2009 led magtorganerne i Nordkaukasus de største tab netop i Tjetjenien; her var tabene dobbelt så mange som sommeren før. I 2009 blev der i Tjetjenien udført en serie terroraktioner, bl.a. med anvendelse af selvmordsbombere.

'Tjetjeniseringen' af konflikten havde en mærkbar indvirkning på bekæmpelsen af den væbnede modstand i de foregående år. Men det står klart, at denne ressource er opbrugt i dag, republikkens myndigheder er ikke i stand til at indfri præsident Ramsan Kadyrovs løfte - helt at tilintetgøre undergrundsbevægelsen og de militante. Hvad mere er: Det 
totalitære regime i Tjetjenien, der bygger på vold og frygt, fremkalder selv ny modstand. En del af de unge drager igen op til de militante i bjergene. Denne udvikling af situationen reagerer republikkens magthavere yderst barsk på, og de satser igen på ulovlig vold. Denne vold antager stadig større omfang, og den udføres åbent og demonstrativt, fx stiger antallet af bortførelser. Menneskerettighedsorganisationen Memorial har for året 2009 registreret bortførelser af 96 personer i Tjetjenien (2,3 gange flere end året før).

Omstændighederne omkring bortførelserne viser, at repræsentanter for magtorganerne er meddelagtige i udførelsen af disse forbrydelser. I denne forbindelse skal man være opmærksom på, at Memorial fra juli til midten af december 2009 midlertidigt indstillede sit arbejde i Den Tjetjenske Republik.

\section{Kun toppen af isbjerget}

Dertil kommer, at ofrene for bortførelserne og deres slægtninge i den senere tid er blevet stadig mere bange for at klage til officielle myndigheder eller til menneskerettighedsforkæmpere af frygt for repressalier. Derfor registrerer Memorial kun 'toppen af isbjerget'.

I Tjetjenien benytter myndighederne sig ofte af gidseltagninger, og i 2009 fortsatte kampagnen med at smadre huse, der tilhører slægtninge til de militante.
Ordensmagten i Den Tjetjenske Republik er infiltreret af folk, der er uddannet i vold i illegale væbnede grupper, som principielt fornægter selve begrebet 'lovlighed'.

Det er ledelsen af Tjetjenien, der offentligt udsteder direktiver for udøvelsen af illegitim vold i republikken, herunder henrettelser uden rettergang. Memorial ligger inde med optagelser af udtalelser af den tjetjenske præsident og andre embedsmænd i republikkens tv om, at det finder sted. Som følge heraf er det kommet dertil, at der den 7. juli 2009 i centrum af landsbyen Akhkintju-Borsoj blev foretaget en offentlig henrettelse uden rettergang af en person, der var mistænkt for at støtte de militante.

\section{Blåstempler chikane}

I Tjetjenien udsættes menneskerettighedsaktivister for diverse former for undertrykkelse. Højtstående embedsmænd i Tjetjenien har offentligt flere gange fremstillet medarbejdere i menneskerettighedsorganisationer som fjender af republikken og som terroristhåndlangere. Det skaber forhold i republikken, hvor bare det at kaldes 'menneskerettighedsforkæmper' bliver yderst farligt og blåstempling af forfølgelse af disse.

Den 15. juli 2009 blev den ledende medarbejder ved Memorial, Natalja Estemirova, bortført i Grosnij og derefter myrdet. En række begivenheder forud for mordet, såvel 
som omstændighederne omkring udførelsen af selve forbrydelsen giver os solid baggrund for at nære mistanke om, at den blev organiseret og udført af repræsentanter for staten.

Efter mordet på Estemirova måtte Memorial midlertidigt (indtil 16. december 2009) indstille sine aktiviteter i Tjetjenien.

Myndighederne lægger også et systematisk pres på de lokale ngo'er, så mange er blevet tvunget til at omlægge deres virke fra forsvar for menneskerettighederne til kun socialt arbejde. Og de er tvunget til selvcensur.

Den 11. august 2009 blev lederen af ngo'en 'Vi vil redde en generation', Sarema Sadulajeva, og hendes mand Umar (Alik) Dsjabrailov bortført fra ngo'ens kontor i Grosnij. De blev kørt bort i en bil af ukendte bevæbnede personer, der ikke skjulte deres ansigter og erklærede, at de kom 'fra organerne'. Næste morgen blev de bortførtes legemer med spor af tortur og ydmygende behandling fundet i Grosnij i en bils bagagerum. Det er indlysende, at det kun er statens medarbejdere, der kan bortføre mennesker ved højlys dag uden at dække deres ansigter til og fortsat gå frit og frejdigt rundt i Grosnij med våben $\mathrm{i}$ hånd.

\section{Udenrigs spørger Orlov:}

Hvad vil Moskva gøre efter terrorangrebet $i$ Moskvas metro $i$ marts 2010?
"Det er stadig umuligt at sige, hvordan situationen vil ændres. Vi er selvfølgelig bekymrede for, at russiske myndigheder vil reagere blot styret af øjeblikkelige følelsesmæssige reaktioner og ikke tænker på de langsigtede perspektiver. De vil sikkert som sædvanlig ønske primært at fremstå som effektive myndigheder, der er parate til at give terroristerne barske svar. Vi er vænnet til lidet gennemtænkte reaktioner, der kun forværrer situationen. Men vi får se".

Er en løsning overhovedet mulig med den aktuelle russiske ledelse? "Man må alvorligt tvivle på, at situationen kan ændres med den aktuelle russiske ledelse, fordi Vladimir Putin stadig er ved magten. Formelt er han ikke præsident, men alligevel noget nær almægtig. I hans tid ved magten blev situationen ført ind i en blindgyde. Men vi må stadig bevare håbet om, at præsident Dmitrij Medvedev kan vise sig i stand til at bryde den 'onde cirkel' af vilkårlig vold fra begge sider, som blev skabt mens Putins var ved magten. Men igen, vi får se”.

Oleg Orlov er formand for organisationen Memorial, der blev grundlagt $i$ 1991 til forsvar af menneskerettigheder $i$ Rusland. Memorial fik sidste år EuropaParlamentets Sakharov Pris.

(Oversat fra russisk af Lars P. PoulsenHansen) 